\title{
Post-Crisis Growth and Development Slowdown of Central Eastern European Countries from the Middle-Income Trap Perspective
}

\author{
Krisztina SőreGa \\ Received: 27.02.2018; Revised: 13.03.2018; Accepted: 14.05.2018
}

\begin{abstract}
There seems to be no compelling reason to argue that the financial crisis of 2007-08 has significantly contributed to the deepening of centre-periphery based development issues in the European Union. In current paper the post-crisis increase and development slowdown of Central Eastern European Countries - and from a broader perspective the post-transition growth path of the region is examined. One of our main hypotheses is that the process of accession to the EU - by stimulating foreign investment to the region - has strongly contributed to the significant pre-crisis development and to the post-crisis persistent growth slowdown in Central Eastern European Countries. During the recent crisis, the above-mentioned nation states have been dealing with several socio-economic difficulties raising considerable financing needs towards the IMF. It can be assumed that the long-standing structural problems of the post-Soviet countries combined with the latest protracted recession have created a middle-income trap related situation in the examined region. In this paper, we are providing a brief review of the CEECs' development from central planning towards market economies state followed by a global economic outlook of the post-2008 growth. We are also analysing some middle-income trap episodes of the region focusing on the special case of Hungary's post-transition development path.
\end{abstract}

JEL codes: O11, O47, O57

Keywords: Economic growth, Middle-income trap, Growth slowdowns, Financial crisis

\section{Introduction}

There is ample support for the claim that since the financial crisis of 2008, several Central Eastern European Countries (CEECs) have been experiencing a significant growth slowdown. In November 2017, the European Bank for Reconstruction and Development published its newest Transition Report 2017-2018 declaring that certain Central and Eastern European economies have become stuck in the so-called middle-income trap requiring new growth models and strategies to develop (EBRD, 2017). Besides growth stagnation, considerable convergence slowdown can be detected in European transition economies provoked by a complex set of structural problems (Bieńkowski, 2016). According to a V4

a Faculty of Science of Public Governance and Administration, National University of Public Service, Budapest, Hungary. e-mail: krisztina.soreg@gmail.com 
Countries' analysis, due to the protracted recession period, a new steady-state level may evolve concerning output growth and thus further protruding V4 economies' catching-up process towards the more developed economies of the European Union (Golonka et al., 2015). Other authors argue that along with the most popular explanations, it has to be considered that in middle-developed countries - among lower value added activities - manufacturing is the main pushing factor of growth which will not result long-term economic development (Cywiński et al., 2016).

On these grounds, there is a growing importance to pay more attention to the development path of the Central Eastern European economies because they have always represented a special role within the EU's overall development. On one hand, members of the former Soviet Union had been composing such a heterogeneous socio-economic community before the regime change that after 1989, each of their development scenarios may be considered unique. On the other hand, the 2004 enlargement of the EU with the 10 new states have further contributed to the growing regional differences of the integration. Also, there has been an inconclusive scientific debate about whether certain CEECs are indeed, affected by the (middle-) income trap or not. In our paper, the discussion centres on the persistent growth slowdown that has been undergoing in case of the given Central Eastern European Countries and we also aim at revealing the main possible causes as well as effects of latter situation. Our research is carried out regarding the following economies: Bulgaria, Croatia, Czech Republic, Hungary, Romania, Slovakia and Slovenia.

There has been an inconclusive debate about whether the enlargement of the Union had played a primary role in the economic growth and development of the above listed postcommunist countries. Nonetheless, in this study, the issue under discussion is the relation between integration into the world economy (EU accession) and current growth slowdown, protracted recession of the CEECs. Analysing the relation between economic growth and multiple variables such as external balance, FDI inflow, trade openness, etc., we are dealing with our main hypothesis claiming that the process of accession to the European Union by stimulating foreign investment to the region - has strongly contributed to the significant pre-crisis growth as well as to the post-crisis persistent growth slowdown in Central Eastern European Countries. In frames of the research we also investigate whether the economic growth of the CEECs in the course of the past 10-20 years shows correlation with their initial (1995) income level. Our third premise focuses on the question whether there is a connection between a deeper and more prolonged recession and greater growth in case of the 8 economies.

Following the brief introduction of the study, in Section 2 we are going to review the main milestones of Central Eastern European region's post-transition growth with some descriptive statistical findings for the period from 1996 to 2016. Subsequently, the relation between external balance and economic growth is going to be touched upon aiming at examining our first hypothesis. Section 3 provides a short outlook of the post-crisis economic growth in world economy. Next, in Section 4, some middle-income trap related CEECs will be revealed by detecting persistent growth slowdown episodes and preparing analyses concerning the second and third hypothesis of our paper. As a final episode, we briefly introduce the post-transition development path of Hungary, the country that is given particular attention in this paper since it was one of the most severely crisis and also recession stricken area of the examined country group. 


\section{From Central Planning to Market Economies}

\subsection{Key elements of post-transition growth in the CEECs}

It is undeniable that Central Eastern European Countries have been long dealing with severe economic backwardness representing the periphery region of the European Union from territorial as well as economic aspects. Following the collapse of the Soviet Union, it has taken a longer time to develop, implement or achieve such processes as increased productivity and faster economic growth. Besides a severe economic turmoil, the regime change provoked several other problems at micro and macro level: increasing unemployment rate, declining output, growing government expenditures, worsening disparities among different social groups and geographic territories. The systemic transformation driven negative outcomes had - not surprisingly - the most massive impacts in Bulgaria, the Czech Republic and Romania (Bieńkowski, 2016).

However, between 1995 and 2003, GDP per capita (labour productivity and real consumption) increased considerably faster than in other regions of the European Union (Kornai, 2005). The next milestone was in 2004 when the Union was enlarged with a set of new member countries. To continue, the second most intensive period was induced by the global financial crisis of 2007-2008. As it is known, the European Union - as the world's most open integration - experienced a significant recession period. Not surprisingly, countries on the EU's peripheries - among them the already mentioned CEECs - have been also facing a severe market crisis.

As regards the question of transition economies' development, Kornai puts forward the view that latter process can be characterized by six main features in case of Central Eastern European region and thus may be considered as a unique phenomenon (Kornai, 2005):

- Changes resulted in the formulation of capitalist systems and democracies;

- There was a complex and overall process of transformation regarding economy, political structure, political ideology, legal system and social stratification;

- Non-violent transition was realized;

- Changes were not preceded by war and thus could be developing in a peaceful way;

- Transition period was extremely short, lasting for 10-15 years.

Although due to many internal and external reasons, transition was an essential and inevitable outcome for the region, it is important to highlight that the development gap between the examined countries and the western economies had already existed for a considerable time, especially deepening between 1820 and 1913. The situation was further worsened when it became evident that - among many other factors - the Soviet Union had not been able to deal with the competitiveness of the more developed economies (Podkaminer, 2013). Whereas there was a catching-up period following 1995 that had lasted until the recent economic crisis, we have to add that latter convergence phase was not substantiate enough to provide long-term economic growth in the future (Hüttl et al., 1998). Concerning the semi-development of post-soviet countries, Janossy (1969) claimed that the unsubstantiated economic structure had not resulted in true convergence towards the Core economies' level of development. 
On these grounds, it can be assumed that the financial crisis and recession has further contributed to the slowing of convergence attempts of the CEECs, however, there are notable regional differences to be taken into account. Going back to the transition phase that was quiet deficient in many respects, the biggest losers of it were probably those economies which had been primarily dealing with heavy industry, mining or agricultural production. On the contrary, countries having a relatively developed infrastructure, transport connections and skilled labour force were able overcome difficulties much faster. Between 2000 and 2004, CEEC Member States' economic performance was above EU's average. Still, after the integration of the 10 new states, intra-economy regional development gaps have intensified. For example, in Slovakia there was a 3.1 times difference between the most and least developed regions in 2004 compared to the 2.9 level of 2000. Poland was producing the most equal territorial level of development: a factor of 2.2 between the richest and poorest regions (KSH, 2007).

Figure 1 illustrates the economic growth of the 8 selected Central Eastern European Countries between 1996 and 2016 compared to EU level on the basis of World Bank's World Development Indicators data (WDI, 2017) in two separate graphs. It is evident that although there were some serious differences among members' pre-crisis performance, an overall positive tendency could be observed following the transformation crisis of 1995 . However, in case of our country set, the biggest decreases emerged in 2009. The deepest decline took place in Slovenia (-7.8\% in 2009) while the highest increase occurred in Slovakia (10.8\% in 2007). The average annual Gross Domestic Product of CEEC-8 was $-5.06 \%$ and $-4.38 \%$ in the EU in 2009. As it has been already mentioned, Poland represented an outlier factor with its 2.82 growth during the most critical year.

Table 1: Descriptive statistical findings in CEEC-8 and EU (1996-2016, \%)

\begin{tabular}{lrrr} 
& Average & Minimum & Maximum \\
\hline Bulgaria & 2.84 & -5.61 & 7.68 \\
Croatia & 2.05 & -7.38 & 6.65 \\
Czech Republic & 2.46 & -4.84 & 6.88 \\
Hungary & 2.24 & -6.56 & 5.01 \\
Poland & 3.98 & 1.25 & 7.03 \\
Romania & 2.87 & -7.07 & 8.46 \\
Slovakia & 3.96 & -5.42 & 10.80 \\
Slovenia & 2.55 & -7.80 & 6.94 \\
European Union & 1.72 & -4.38 & 3.88 \\
\hline Source: Author's calculations from WDI (2017)
\end{tabular}

Using some basic descriptive statistical methods, we have summarized the key elements of economic growth over the past 20 years (Table 1). Regarding average annual growth, Poland has provided the highest values $(3.98 \%)$, while Croatia has become a laggard economy $(2.05 \%)$. A closer look at the data reveals that concerning the EU average, all the 8 countries managed to exceed the 1.72 value between 1995 and 2016 .

\subsection{Relation between external balance and economic growth}

In the following, we assume that long-term convergence of an emerging market economy referring to countries in the CEEC region - is only possible if the elevated rate of economic growth is not accompanied by a massive current account deficit. If the current account balance is negative for an extended period of time, the given country will start to accumulate 

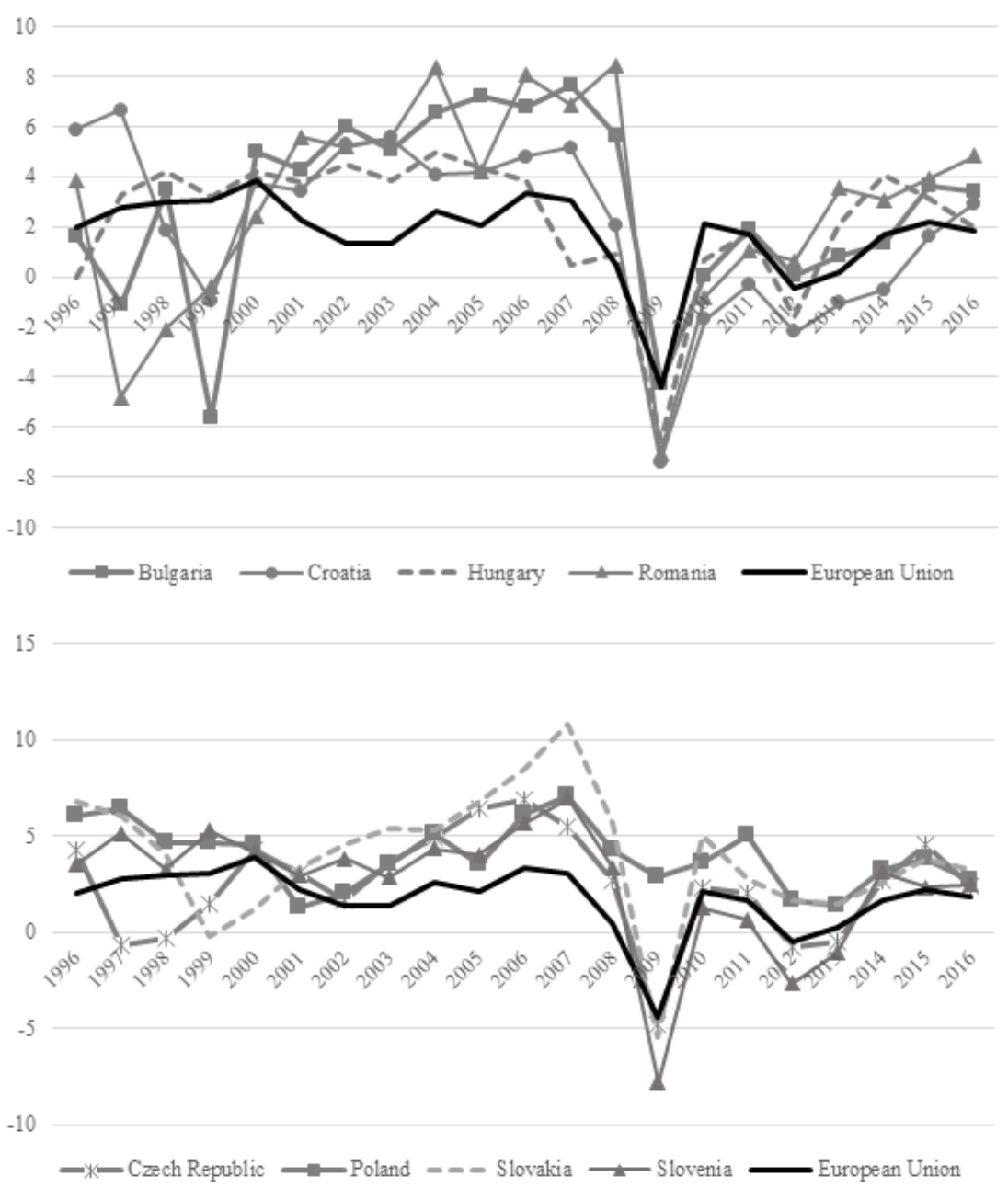

Figure 1: GDP growth between 1996 and 2016 in CEECs (annual, \%)

Source: Author's calculations from WDI (2017)

an unhealthy amount of external debt, while the inflow of foreign direct investment (FDI) reduces the percentage of domestic assets owned by local firms or households. In the long run, the latter leads to a growing gap between GDP and GNI (Gross National Income), as the share of foreign-owned assets in domestic production becomes more pronounced. Ceteris paribus, the outflow of capital gains deepens the already existing deficit in the current account and creates demand for further external financing in the form of debt or foreign equity.

The considerable risks associated with excessive economic growth fuelled mainly by FDI inflow and to a lesser extent, by portfolio investments and debt financing are well known regarding the multiple currency crises and balance of payments adjustments which have occurred in world economy since the 1970s, when controls on world capital markets were gradually lifted. The Mexican peso crisis of 1994-95, the great East Asian financial crisis of 
1997 or the 1998-2002 Argentine great depression have emerged in middle-income countries and were preceded by a period of rapid economic growth. The Great Recession in 2009, which followed the global financial crisis of 2008, was the most severe in the CEEC region and in some other countries in the Eastern periphery of the European Union. Most of the CEECs among with Ukraine, Turkey and the Russian Federation experienced a 6 to $15 \%$ drop in per capita GDP within a year. In Latvia and Estonia, the depth of recession reached 16.8 and 19.0 percentage points.

It has been argued that frictions on the global financial markets could lead to dispersions in the rates of return to investment. Excessive FDI inflow directed towards an emerging economy may temporarily push the level of economic growth above the long-term rate, improving profit-related market expectations and in the end, attract even more foreign investors into the given country. While it has been demonstrated that the existence of these 'bubbly' growth episodes require some investments to be dynamically inefficient (these inefficiencies are creating the demand for bubbles). The dynamic inefficiency, however, might be generated by the episode of elevated economic growth itself (Martin \& Ventura, 2010).

Small-sized middle-income countries with an elevated level of openness and economic freedom in a globalised world could be highly prone to the formation of such growth bubbles, especially when rates of return to investment in the advanced countries are falling and therefore, more and more capital is getting allocated to emerging markets, where the expected returns and risks are both larger.

In order to examine further the relation between external (im)balance and long-term economic growth, we have to introduce the concept of Net International Investment Position (NIIP) to our analysis, which expresses an economy's net worth. Literally, the value of NIIP in a country in any year equals the value of the assets that resident economic agents of the given country own abroad, minus the value of domestic assets owned by foreigners. Economic convergence by elevated GDP growth may be sustainable if it is not accompanied by a current account deficit large enough to significantly change the NIIP to GDP ratio of the given country in a negative way.

Any change in the NIIP to GDP ratio equals the current account to GDP position of the preceding year, the rate of economic growth and valuation effects, expressed in the following equation (1).

$$
\triangle\left(\frac{N I I P}{Y}\right)_{t}=\left(\frac{e_{t}}{e_{t-1}}\right) \frac{1+\frac{C A_{t-1}}{Y_{t-1}}}{1-\frac{Y_{t}}{Y_{t-1}}}-1
$$

where $Y$ stands for annual GDP, $e_{t}$ and $e_{t-1}$ are the annual average exchange rates weighted with respect to the denomination of foreign assets and liabilities and $C A_{t-1}$ is the current account balance of the preceding year.

In a world without large-scale international capital flows, a current account deficit should contribute to the fall of the local currency value. However, as strict capital controls are not in effect any more, a country's current account position is no longer relevant in the development of exchange rate as currency transactions for long-term investment and speculative purposes are dominating the market. Therefore, we can assume that the change of the value of the local currency compared to a basket of other relevant currencies is not dependent on trade or current account balance and in the long-run, will have an expected value of zero. 
If the exchange rate is unchanged and we disregard the valuation effects, then with substituting $c_{t}$ for the current account to GDP ratio and $g_{t}$ to the rate of economic growth, the change in NIIP to GDP will be zero or positive with the following condition (2):

$$
1 \leq \frac{1+c_{t}}{1-g_{t}}
$$

Assuming an empirically observable, near-linear relation between current account balance and GDP growth rate, we can express the rate of annual economic growth as a function of the current account (3):

$$
g_{t}=\hat{\alpha}+\hat{\beta} c_{t}+\epsilon
$$

where $\hat{\alpha}$ is the observable growth rate with a perfectly balanced current account and $\hat{\beta}$ is a parameter with a negative sign which expresses the impact of a one percentage point decline of the rate of economic growth. Both parameters can be empirically estimated from the available data regarding the CEEC group between 1996 and 2016, the OLS estimation gives us a most likely value of $\alpha=2.363$ for the long-term balanced growth rate and $\beta=0.319$ for the impact of external financing of growth potential.

NIIP to GDP ratio remains unchanged (or changes in a positive way) if the following condition (4) is met:

$$
c_{t} \geq-\left(\frac{\hat{\alpha}}{1-\hat{\beta}}\right)
$$

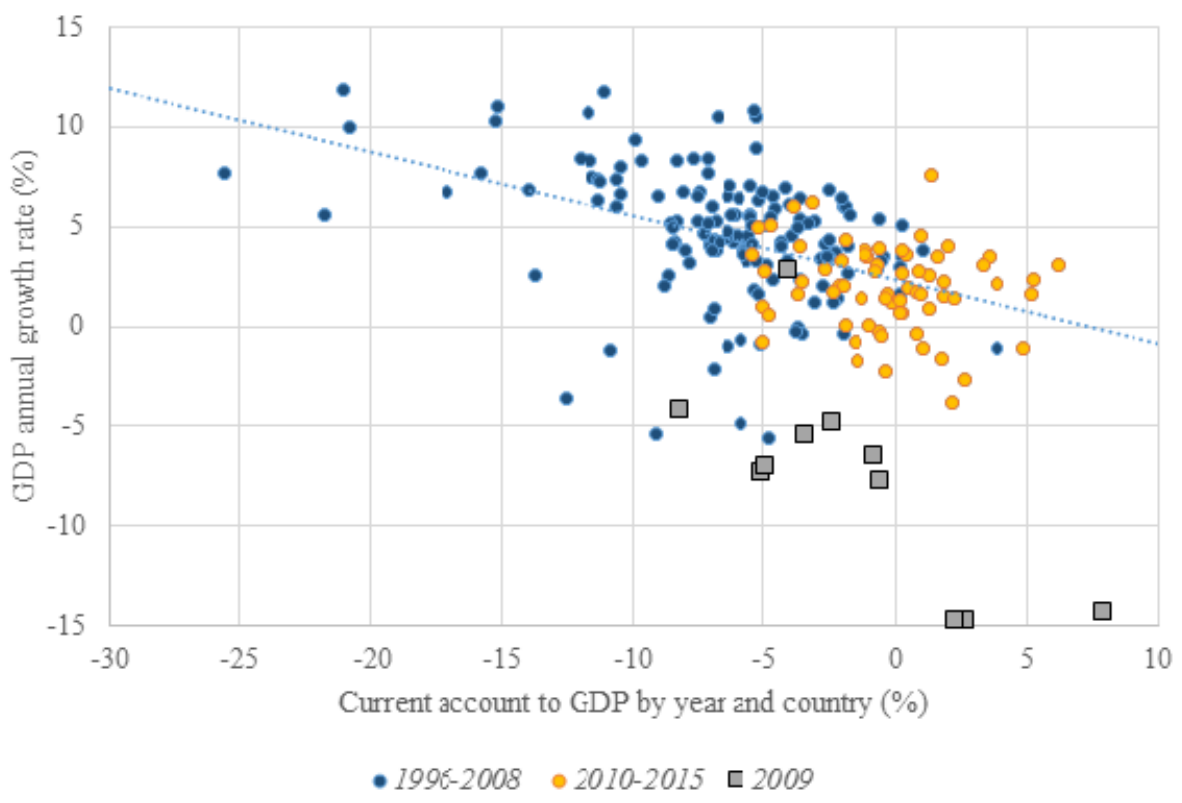

Figure 2: Relation of annual GDP growth rates to external balance by year and country Source: Author's calculations from WDI (2017) and EUROSTAT (2017) 
Using the growth rate and current account balance data pairs for the CEEC-11 country group between the years of 2006-2016, excluding the recession year of $2009(\mathrm{~N}=220)$, current account deficit should not be greater than $3.47 \%$ of GDP in order to prevent the degradation of the given country's NIIP.

Table 2: Relations with annual GDP growth between 1996 and 2016 (excluding 2009) coefficient std. error p-value sig. 95\% confidence Pearson-r

\begin{tabular}{|c|c|c|c|c|c|c|c|}
\hline & & & \multicolumn{5}{|c|}{ interval } \\
\hline Current Account Balance & -0.319 & 0.039 & $3.3 \mathrm{E}-14$ & $* * *$ & -0.396 & -0.242 & 0.493 \\
\hline Net FDI Inflow & 0.31 & 0.077 & 0.0000745 & $* * *$ & 0.159 & 0.462 & 0.271 \\
\hline Change in trade to GDP ratio & 0.023 & 0.085 & 0.789 & n.s & -0.145 & 0.19 & 0.019 \\
\hline Change in Economic Freedom Index & 0.0029 & 0.0035 & 0.406 & n.s & -0.004 & 0.0099 & 0.058 \\
\hline
\end{tabular}

The scatter plot in Figure 2 was created to investigate the first hypothesis of our research, i.e. the economic integration as well as the process of EU accession played a key role in the pre-crisis, relatively high growth and post-crisis deep recession of the CEECs. In Figure 2 pairs of data are viewed by the examined countries and years (with the exception of 2009): there are altogether 220 data points (20 years x 11 countries). Dark spots indicate the precrisis and lighter ones illustrate the post-crisis data. It can be seen that the relation between annual GDP growth rate and current account to GDP is relatively strong. What is more, the direction and slope of the relation did not change before and after the crisis since no structural break was detected. The coefficient of the current account balance showed in Table 2 has a -0.319 value meaning that if current account balance decreases by 1 percentage point, GDP growth rate will increase by 0.319 percentage point. Of course, some other parameters have also been tested in our model. For example, net FDI inflow indicates the balance of FDI inflow and outflow compared to GDP percent in the given year. Latter factor is positive almost in every period. The coefficient is 0.310 that practically corresponds to the current account balance slope value in absolute terms. To continue, in case of the change in trade to GDP ratio, the relation is not significant because the p-value is 0.789 . The situation is quite similar regarding the change in Economic Freedom Index (Fraser Institute, 2017) by measuring annual change it can be seen that the relation is week with a $0.406 \mathrm{p}$-value. As a conclusion, only current account balance as well as net FDI inflow show a strong and significant relation with annual Gross Domestic Product growth. Similar coherences and factors were revealed in frames of the Economic Papers in 2009 by Rapacki and Próchniak (2009) - the authors also examined such elements as progress of structural reforms or aid inflow via some regression equations focusing on the real convergence of Central Eastern European Countries to EU-15. Their research also concludes that the convergence process of the region may take from 8 to 33 years (Rapacki \& Próchniak, 2009).

\section{Post-Crisis Economic Growth - Global Economic Outlook}

Despite the fact that the European Union is the world's largest and most opened economic integration, its growth has been stagnating approximately from 2005. Some analyses precise that this constant stagnation - sometimes even regression - occurred after the launch of the Single Market Programme as well as the European Monetary Union (EMU). 12 years after the end of World War II, the European Economic Community was established. During this period the Community managed to produce relatively high growth as well as convergence 
to the United States in levels of per capita income mainly due to the effects of post-war reconstructions and economic boom. However, such convergence could only be observed until the 1980s. The economic performance has been hardly influenced by to following milestones of the integration (Majone, 2012):

- Common trade policy;

- Customs union;

- Supranational competition policy;

- Extensive harmonization of national laws;

- The establishment of the single market;

- Centralized monetary policy.

To continue, GDP showed further diverging tendency in comparison with the US economy during the 1990s. In 2009 the world economy experienced its most severe crisis of the previous 60 years. In the long run, there have been such negative externalities as the extreme indebtedness of governments or the significant level of job losses (Attila, 2013). What is more, the subprime crisis of 2008 can be characterised as an outlier in the history of crises of capitalist system, since the processes of globalization have connected the financial markets so tightly that all the effects could spread from the United States to the rest of the world with a much higher intensity compared to the crisis of 1929 (Attila, 2013).

Table 3: The difference of the GDP per capita growth rate between 2009 and 2014 compared to the

\begin{tabular}{lrrrrrrrrr}
\multicolumn{7}{c}{ average growth rate between 2002 and 2007} \\
Country & Average & 2008 & 2009 & 2010 & 2011 & 2012 & 2013 & 2014 & $2010-2014$ \\
& $(2002-2007)$ & & & & & & & & \\
\hline USA & 1.75 & $-2.98^{*}$ & $-5.64^{*}$ & -0.09 & -0.64 & 0.28 & -0.6 & 0.73 & 0 \\
EU & 1.99 & $-2.00^{*}$ & $-6.80^{*}$ & -0.19 & -0.62 & $-2.28^{*}$ & $-2.12^{*}$ & -0.49 & -1.1 \\
Japan & 1.51 & $-2.50^{*}$ & $-6.92^{*}$ & $3.24^{* *}$ & $-2.24^{*}$ & 0.15 & 0.21 & $-1.81^{*}$ & -0.1 \\
China & 10.57 & $-1.49^{*}$ & $-1.89^{*}$ & -0.65 & $-1.79^{*}$ & $-3.44^{*}$ & $-3.43^{*}$ & $-3.76^{*}$ & -2.6 \\
India & 6.39 & $-3.87^{*}$ & 0.68 & $2.46^{* *}$ & $-1.10^{*}$ & $-2.97^{*}$ & $-2.67^{*}$ & $-1.92^{*}$ & -1.2 \\
Brazil & 2.57 & $1.63^{* *}$ & $-3.78^{*}$ & $4.02^{* *}$ & -0.73 & 0.85 & -0.95 & $-4.03^{*}$ & -0.2 \\
\hline
\end{tabular}

Source: Author's calculations from WDI (2017)

In order to get a deeper understanding of post-crisis processes in the EU as well as CEEC-8, in what follows, we are presenting a brief report on the performance of the main economic centres of the world (the "Triad" - USA, EU and Japan and three of the BRIC economies - China, India and Brazil) between 2002 and 2014. Table 2 shows the - positive or negative - change of GDP per capita between the period of 2008 and 2014 compared with the pre-crisis average rate from 2002 to 2007 in six chosen economies (USA, European Union, Japan, China, India and Brazil). The asterisk cells indicate that in the given year there was an at least 1 percentage point decrease $(*)$ or growth $(* *)$ in comparison with the 2002-2007 average. In case of the USA it can be observed that between 2010 and 2014 the annual GDP growth fluctuated around the pre-crisis level (1.75\%). However, in Japan there was higher oscillation - nonetheless it had achieved a higher than average growth before 2010, in 2011 it experienced a severe recession due to the destructive earthquake of 2011. Despite, the 2010-2014 growth rate is only 0.1 percentage point lower than the pre-crisis value. Within the group of the traditionally developed economies, only the European Union had a smaller growth rate than the 2002-2007 average. Nevertheless, we have to remark that the EU - 
again - can be visualized as a special case since it is composed of several countries with different levels of development: Germany, the Netherlands, the Northern countries and the United Kingdom show no significant decrease while nation states as Greece, Spain, Portugal or even Italy have been in crisis in the previous period as well. In the case of Brazil no outstanding growth tendency can be experienced before the crisis and the difference between the average value as well as the 2008-2014 period is relatively small (0.2 percentage points). In China growth has slowed by $3 \%$ but its current growth rate still can be considered quite fast compared to other emerging countries. During the crisis of 2008, Brazil, India and China have been the less affected regions in our analysis while the European Union, where state interventions were hardly effective, is at the bottom of the league. Furthermore, its post-crisis recession has been the most long-lasting.

As we have already concluded, crisis management within the EU has not been that successful and was focused mainly on the economic dimension of the depression (e.g. liquidity issues of the banks and also solvency problems of people). There are several side effects of the current crisis in Europe (Attila, 2013):

- The default of the "unconstrained spending" state of Greece;

- The failure of the banking sector after the credit boom;

- The threat of the enormous state debt in Italy.

What possible scenarios can be developed in order to maintain effective crisis management in the European Union? On one hand, we have to mention the neo-functionalist approach according to which we have to interpret the "... European integration as a technocratic process driven by the need to solve immediate economic problems and deliver tangible material benefits." (Beneš \& Braun, 2014, 16). On the other hand, according to the functionalist point of view, such elements as geographical, legal and institutional integrity should not be seen as the only scopes since the effective management of the current situation within the Union provides much far-reaching goals. The already mentioned geographic "spill over" effect as well as the intergovernmental way of policy-making suggests the so-called multilevel (or multi-speed) model of integration. However, a consolidated Eurozone in a two-tier European Union (two-speed integration) should be also considered as a next step (Beneš \& Braun, 2014).

Between 2010 and 2014, EU's overall economic performance was below the developed countries' achievement but since 2015 it has exceeded latter level. In 2016 each EU Member State's GDP volume increased with the exception of Greece. The positive change was the biggest in case of Ireland achieving 5.2\%. Concerning the Central Eastern European region, the following economic output data were observed in the above-mentioned year: $4.8 \%$ in Romania, $3.3 \%$ in Slovakia, $2.8 \%$ in Poland and $2.4 \%$ in the Czech Republic. It has to be added that their GDP has produced a higher increase than in case of Hungary (KSH, 2017).

\section{Central Eastern European Countries in Middle-Income Trap?}

\subsection{Detecting persistent growth slowdowns in the CEEC region}

Researches made in field of growth slowdowns experienced in middle-income economies are definitely not new. Garrett (2004) focuses on the complex growth problems which are widespread in middle-come countries. The author highlights that supporters of globaliza- 
tion have no grounds to give a solid explanation for the stagnation going on in several middle-income countries. As a possible solution for the catching-up, the author suggests for these economies to "tech up" and thus become active participants of the global market and "knowledge economy" (Garrett, 2004).

According to the World Bank annual classification published in 2017, among the $28 \mathrm{EU}$ Member States there are only 2 economies belonging to the upper-middle income group these are Bulgaria and Romania. However, in current study we are identifying the four income categories by comparing the per capita GDP of the given country to the per capita world Gross Domestic Product. Below 50\% all economies can be considered as low income group members. Between 50 and $100 \%$ countries belong to the lower-middle and from 100 to $200 \%$ they are classified as upper-middle income economies. Above $200 \%$ each country makes part of the high income group. Nowadays, particular attention is paid to middleincome economies since many of them tend to 'stuck' in the so-called middle-income trap. Due to a long lasting stagnation of GDP the given economy is not able to upgrade to the higher income level category and thus in the long run, severe socio-economic problems may occur. In frames of current research, the definition of the middle-income trap ("MIT") phenomenon is stated as follows:

- The per capita GDP adjusted for purchasing power of the middle-income economy is making at least $50 \%$ of world average and maximum the double of it;

- 10 years before the slowdown period there is a significant and fast economic growth, what is more, the country is undergoing a catching-up path producing an at least $3 \%$ annual per capita GDP growth as a 10 year average;

- Growth slowdown is being understood as stagnation and not a sudden recession;

- In the course of the minimum 10-year long growth slowdown the per capita GDP growth is close to zero or at most $1 \%$ per year;

- The upper level of the middle-income trap is an income level being 2.3 times the value of the per capita world GDP. Latter may correspond to the current level of development of the Czech Republic or Estonia.

As it can be seen from Table 4, using the above-mentioned method, we can identify 3 middleincome trap episodes in case of Central Eastern European Countries. In Poland, a significant growth period lasted from 1953 to 1975 which was followed by a 14-year long slowdown process (-0.11\% per year). Latter tendency was followed by a subsequent growth rate in 1992 that has been lasting until nowadays. Our next possible middle-income country is Hungary that has witnessed altogether two such episodes. The first one started with a growth period between 1957 and 1978 (3.57\% per year), however, after 1979 until 1989, slowdown took place and had lasted for 11 years. Following the recovery from the transition crisis, a significant growth rate could be observed between 1994 and 2005 (3.61\% per year). To continue, Hungary's second MIT episode launched with the 2006 slowdown period extended until 2015 (0.82\% per year). After 2015, a subsequent growth rate was spotted, nevertheless, it seems that by now, slowdown has possibly ended in this country.

Figure 3 indicates the current account balance as a percentage of Gross Domestic Product in the two MIT economies listed in Table 3 for the period of 1996 and 2017. As it will be later shown, the crisis of 2008 has had quite different effects on Hungary and Poland within the CEEC region. The primer reason is that although by 2008, external financing had played 
Table 4: Growth and slowdown periods of the CEECs in middle-income trap

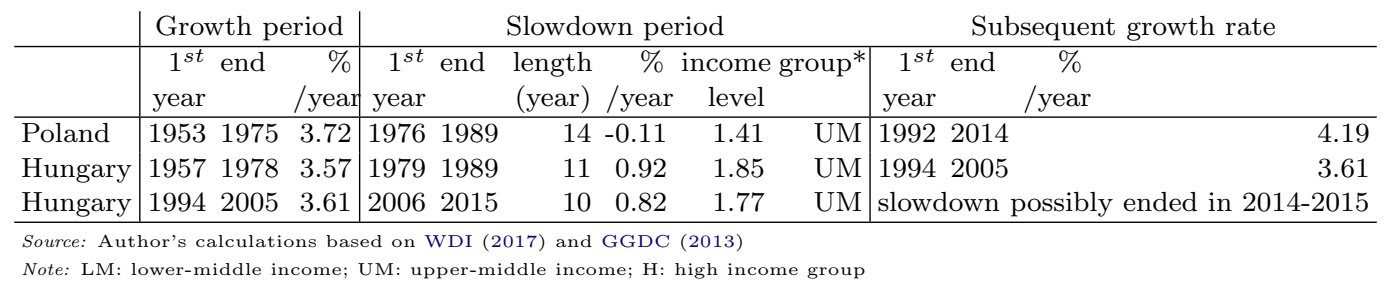

a vital role in GDP growth, domestic consumption had regularly exceeded GNI in both countries. As an outcome, current account had been producing a protracted and significant deficit. Latter deficit was balanced by the positive capital account. However, due to the 2008 financial crisis, the external financing options for Central Eastern European Countries have noticeably decreased - especially in Hungary, where foreign investors considered their further financing activity extremely risky on the basis of high indebtedness (both public and private) as well as negative macroeconomic performance. In Hungary, in October 2008, the Central Bank decided to raise the interest rate by 3 percentage points in one day. What is more, the government also started negotiations with the IMF in order to receive some credit because the market based financing had become non-affordable for the economy. Between 2008 and 2009, the current account balance increased by 7 in Hungary: external financing was practically ceased, domestic consumption and investment significantly declined, GDP fell by $7 \%$ in one year and as a result, deep recession occurred with such further phenomena as very high unemployment rate.

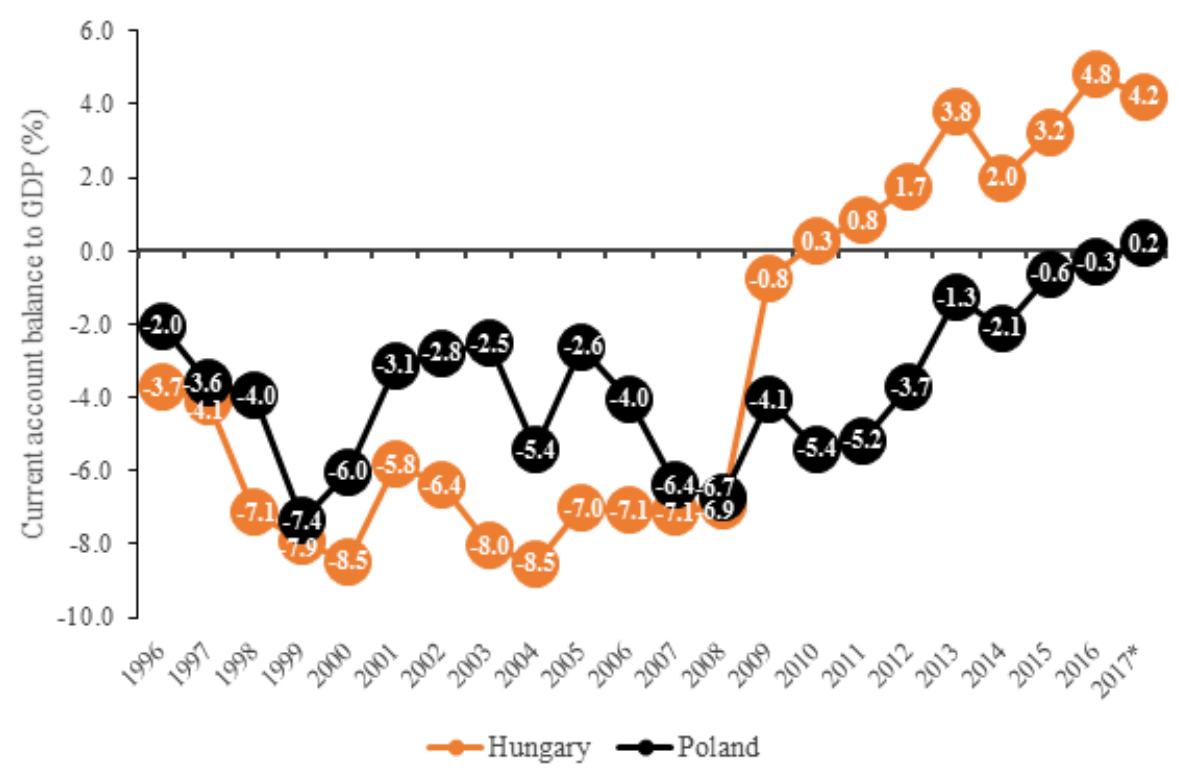

Figure 3: Current account balance as a percentage of GDP in Hungary and Poland 
To continue, Poland had also had deficit before 2008 but at a much smaller extent than Hungary (approximately 2-5\%). At the beginning of the crisis, both private and public deficit were smaller and thus external financing became sustainable in 2008-2009 and also during the subsequent years. What is more, Poland did not carry out radical corrections, instead, these have been realized in the course of 8 years. In contrast, Hungary implemented this action within one year, as it has been already mentioned. Thanks to Poland's gradual correction attempts, economic agents have been able to adapt to these slow internal adjustments. As a result, no recession could be observed in 2008 in Poland and after 2010, a relatively high growth has begun. In Hungary, current account has further increased and has become strongly positive due to the growth within the balance of services (increase of tourism sector and slow growth of consumption).

Garrett (2004) indicates that middle-income countries cannot be viewed as winners of globalization since they could not have utilized a niche in global economy. On one hand, such economies have to deal with a large pool of unskilled or poorly skilled workforce and cannot overcome the continuous adaptation of new technologies and methods (Garrett, 2004). On the other hand, low wages provide competitive advantages only in the short run, however, the lack of high value added export products will certainly prevent the given economy from upgrading to the higher income level group.

We must not lose sight of the fact that tendencies in economic growth have a strong connection with convergence. According to the convergence hypothesis, the per capita incomes of poorer countries are likely to increase at a faster rate than the richer one's and thus all countries should finally converge. However, latter statement remained largely theoretical. There are only two countries - Sweden and the UK - in the European Union which have experienced significant convergence with the United States. Another two countries Germany and Austria - have undergone neither convergence nor divergence and practically stayed at their previous level of relative development. The most diverging countries were Italy and Portugal (GGDC, 2013; EUROSTAT, 2017; BEA, 2017). The available evidence seems to suggest that Western European countries are currently experiencing quite different economic ways of development which is a serious challenge for the European integration. The lack of convergence within the EU raises the question about the sustainability of the Common Market without taking further reforms encouraging economic growth in the stagnating economies.

Concerning the second hypothesis of current paper, we assume that more growth was realized in countries where the initial income level had been lower at the end of the transformation crisis following 1995. In order to illustrate this relation, we have created Figure 4 relying on WDI (2017) and EUROSTAT (2017) data. The diagram was also extended with three additional countries - the Baltic States - with the aim to get a more far-reaching overview of the region. The columns represent constant GDP per capita expressed in PPP based US dollars. Vertical lines indicate the average growth rates, while rhombuses stand for average growth rates between 1996 and 2016. The lower part of the vertical lines below the rhombuses represent the post-crisis growth from 2010 to 2016, while the upper stages show pre-crisis growth (1996-2008). 2009 is the first year of recession. There are actually two economies where income level is exceptionally high: Slovenia and the Czech Republic. In Hungary, Slovakia and Croatia differences are minimal. We can also find that both Bulgaria and Romania were the poorest countries within the group in 1995 and represent the lowest level of development within CEEC-11 nowadays. 
It can be also added that each country's growth has slowed after the economic turmoil: the most significant decrease was experienced in Slovenia, Croatia and the three Baltic States. In Hungary and the Czech Republic both before and after the recent crisis economic growth was relatively slow. On the contrast, Poland has produced the most stable growth: 4.6\% before the crisis and above 3\% nowadays. Between 1996 and 2008, the lowest rate observed in CEEC-11 was of an annual 3\% magnitude and the highest one was $6 \%$ per year in case of the Baltic countries. After the crisis, the average growth rate of the CEECs was $1-3 \%$ and as it has been already stated, Poland is currently representing the most dynamically growing economy of the region. We may conclude that those economies have produced faster growth that had dealt with lower income levels. These results provide confirmatory evidence that our second hypothesis has been proved at a large scale, however, there are some exceptions to be taken into account.

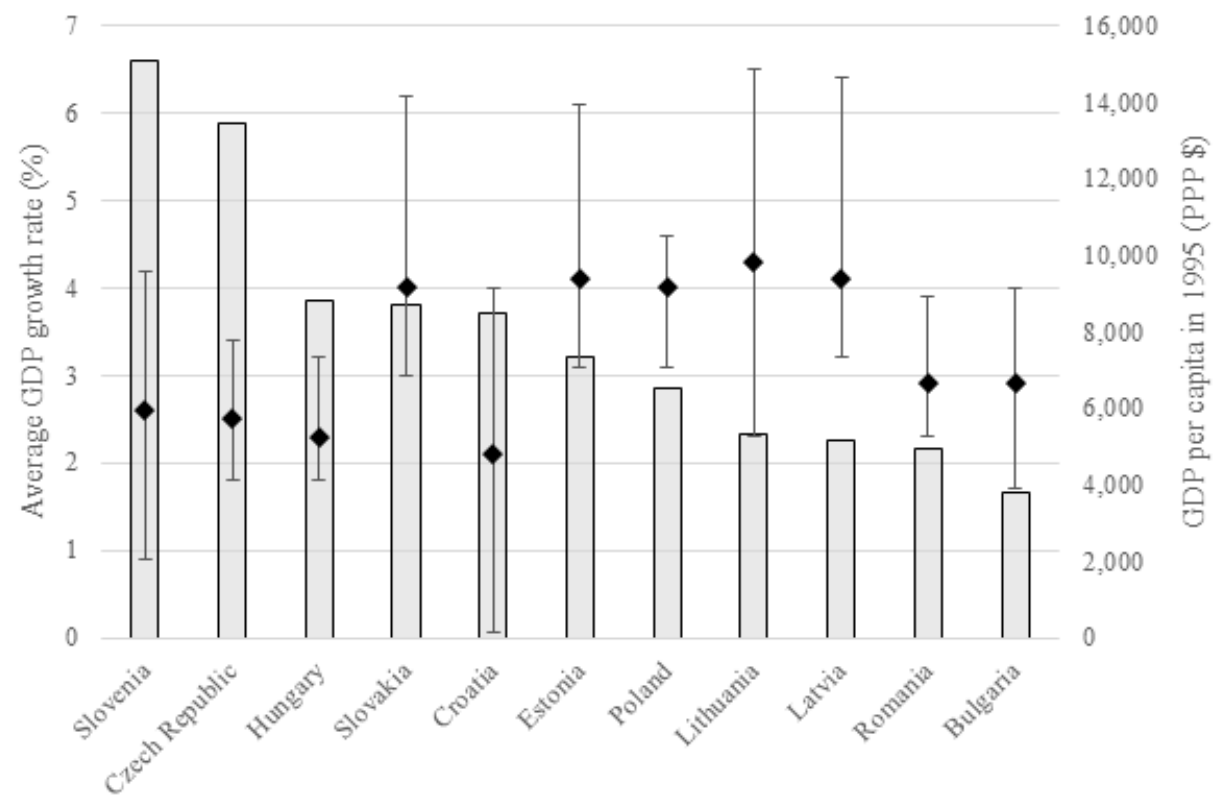

Figure 4: Initial income levels and long-term growth rates in the CEECs

Source: Author's calculations from WDI (2017) and EUROSTAT (2017)

Regarding the third premise drafted in Section 1, we have supposed that higher growth might be followed by deeper recession. As outlined in Figure 5, the horizontal axis corresponds to the average real GDP growth rate between 1996 and 2008, and the vertical axis is the maximum decline of GDP between 2008 and 2013. It is obvious that in most countries 2009 was the year of the deepest recession, nevertheless, in Romania and Latvia GDP decline had lasted until 2010 and in Slovenia as well as Croatia until 2013. Latter two countries experienced recession of the longest duration, while the lowest values could be observed in the Baltic States. In case of the rest CEECs, lower economic growth has been accompanied by a medium scale recession period with the exception of Poland. In Figure 5, Germany and Austria were added to make some comparisons with the examined region. During the crisis, economic growth hardly achieved $2 \%$ in Germany and was slightly above $2 \%$ in Austria. However, recession seemed to be relatively lower in these two economies 
(4-4.5\% fall of GDP) and lasted only for one year. In EU-28, the average pre-crisis growth rate was $2.3 \%$ and the recession reached $-4.5 \%$ value. We may conclude that although the CEEC region was capable of a relatively rapid growth before the economic turmoil, recession turned out to be quite severe within the group. Latter outcome is a typical phenomenon of periphery countries in world economy.

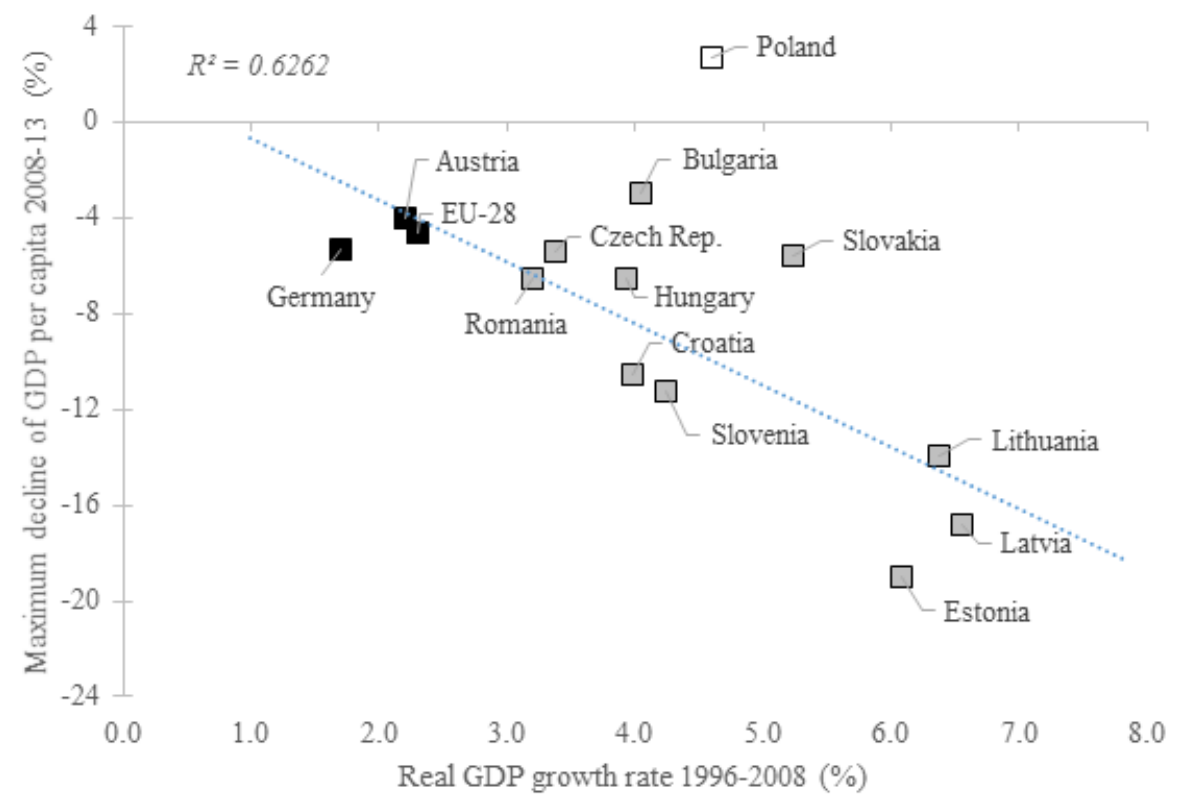

Figure 5: Pre-crisis growth rates and the maximum depth of recession in CEECs compared to given advanced economies

Source: Author's calculations from WDI (2017) and EUROSTAT (2017)

\subsection{Outlook - Post-transition development path of Hungary}

As is other Central Eastern European Countries, in case of Hungary political and socioeconomic transition started in 1989 with such emblematic issues as the proclamation of the Republic of Hungary. Nevertheless, before the most important actions could take place, there had been several antecedents worth mentioning, like for example the strengthening of economic cooperation with the developed western countries or establishing relevant contacts with some international institutions. At the same time, there were many other initiatives greatly contributing to the transition: establishing a multi-party system and private-owned enterprises, building a market economy based system instead of central planning, creation of independent financial institutions, etc. It is doubtless that since the beginning of the 1990s, Hungary's economic development has made a significant progress in many aspects, although there have also been some notable downturn periods concerning its growth. In what follows, we are providing a brief analysis of the country's economic growth from the viewpoint of persistent slowdown cases and the middle-income trap.

After the Council for Mutual Economic Assistance was eliminated that had previously provided the $42 \%$ of export and $40 \%$ of import for Hungary, its market was seriously damaged. As it has been already indicated, in the first years of the new regime, transformation 
crisis caused a serious decline in economic growth: between 1989 and 1993 GDP fell by 18 percentage points and the number of the employed decreased by 1.5 million. Since there was massive capital deficit, the modernization of production could only be realized with the involvement of foreign capital. In order to stabilize the economy, restrictions were introduced to improve the balance of production and consumption, however, they were accompanied by social tensions. The first signs of growth could be observed in 1997 and in the course of the following ten years it achieved a $4 \%$ average value. The main driving force of the catching-up period was to realize EU integration (KSH, 2010).

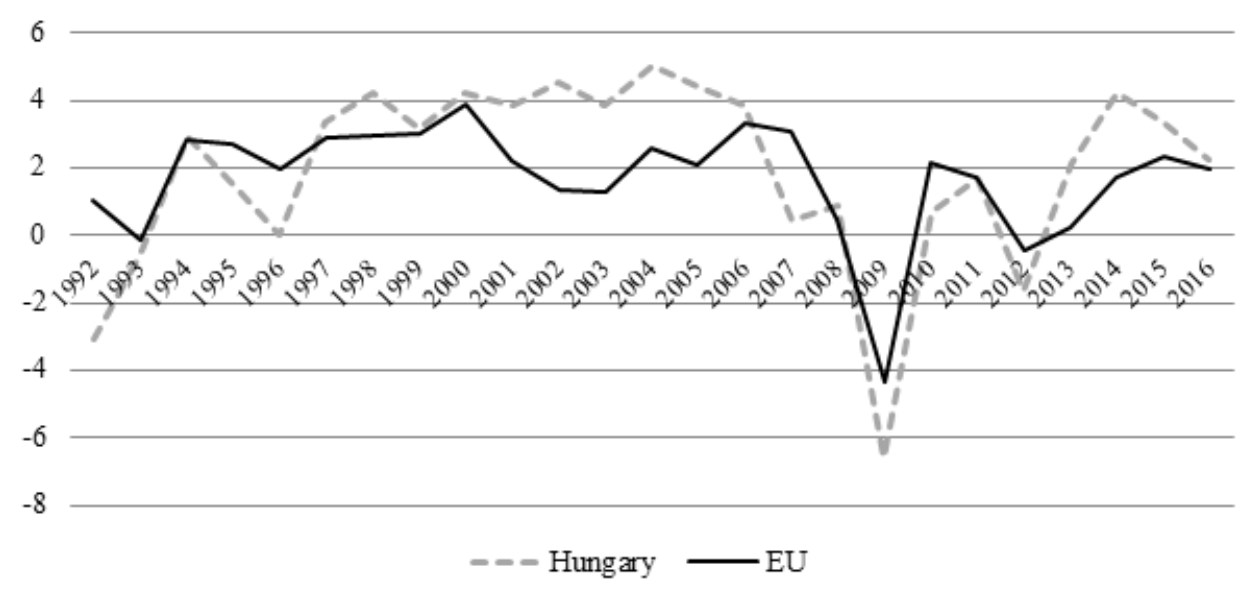

Figure 6: GDP growth rate between 1992 and 2016 in Hungary and EU (annual, \%)

Source: Author's calculations from WDI (2017)

The data provided by World Bank's World Development Indicators are gathered in Figure 6 concerning the annual percentage growth rate of Hungary and the European Union between 1992 and 2016. It is clearly illustrated that the post-1989 low level of development had maintained a promising tendency until 1994 (2.95\%) but was interrupted by the transition crisis similarly to other CEECs. In the next 10 years, the country was able to support a relatively high growth rate until 2006 when government policies directed to reduce the enormous budget deficit that had evolved, contributed to its decrease. During the pre-crisis period - in 2007 -, GDP grew only by 1.1 percentage points (KSH, 2010). The post-2007 turmoil was thus driven by inner and outer factors as well. The worst situation was obviously in 2009: in the European Union annual GDP growth rate reached $-4.36 \%$, while in Hungary it was $-6.6 \%$ (WDI, 2017). The second lowest point could be experienced in 2012 (Hungary: $-1.64 \%$; EU: $-0.43 \%$ ) as it can be seen from Figure 6. The phenomenon being typical for the European Union as well as for Central Eastern European Countries is the so-called double-dip recession which emerges when following a recession period, a shorter recovery interval develops, however, a second recession phase strikes. What is more, the 2012 fall was also deepened by the debt crisis in Southern European economies. Since 2005 (4.39\% per year), the highest rate of Gross Domestic Product Growth was recorded in 2014 (4.23\% per year) in Hungary. In the EU, GDP growth was only $1.74 \%$ in latter year. After 2014 the economic growth of Hungary has been converging to EU average: according to the data, in 2016 it achieved 2.21\% in Hungary and 1.94 in the Union (WDI, 2017). At global level, economic growth of the recent years is attributed to the biggest Asian emerging mar- 
kets' growth. On the basis of the evidence currently available, it seems fair to suggest that Hungary has launched its post-crisis growth since 2013 that is equivalent to a middle-ranking EU Member State in 2016.

\section{Conclusion}

In current paper the issue under discussion was the post-crisis growth and development slowdown of Central Eastern European Countries and from a broader perspective, the posttransition growth path of the region. The CEEC group have always represented a special case within the European Union's overall development. From ex-Soviet Union's satellite countries to EU integrated periphery economies, the region has definitely undergone some long and quite difficult growth path and slowdown episodes over the last - almost 30 - years. In frames of our research, the following results have been revealed:

- With regard to the first hypothesis according to which there is a strong relation between integration into the world economy - EU accession - and current growth slowdown as well as protracted recession of the CEECs, we have stated that latter coherence is significant, especially in case of current account balance and foreign direct investment inflow. Subsequently, larger external imbalance and more inflow of foreign capital contributes to greater GDP increase, however, the net international investment position of the examined countries will likely deteriorate within the same period. It also means that these economies are much more vulnerable than the more advanced EU Member States and may experience much more severe recession episodes following external shocks. What is more, recovery periods tend to be much longer and thus, more devastating for their domestic economic processes.

- The current post-crisis period has revealed that Central Eastern European Countries - in the lack of excessive external financing - are only capable of a relatively slow economic growth which does not exceed annually 2-3\%. On the basis of latter outcome we may raise the question whether the given emerging economies have the possibility to really converge in the long run or not.

- In our second hypothesis, we assumed that more growth had been realized in countries where the initial income level had been lower at the end of the transformation crisis following 1995. As the evidence showed, it also turned out to be proved, however, at a smaller extent, since there were certain countries (e.g. Slovakia) in which economic growth was only slightly dependant on the initial income level.

- The third premise raised the question whether there had been some connection between greater growth and a deeper and more prolonged recession. As Figure 5 indicates, this hypothesis has been also confirmed, especially in case of the Baltic States and of course, in the CEEC-8 group as well. It has been mentioned that nonetheless the CEECs were capable of a relatively rapid growth before the crisis, recession was very severe.

It is undeniable that following the rapid transition towards a market economy, countries of the Central Eastern European region have managed to realize significant economic growth as well as to start their catching-up path towards the more developed core countries. The successful growth episode could be realized due to the immense volume of FDI inflow, especially after the $2004 \mathrm{EU}$ accession. However, as it has been experienced after the recent 
economic and financial crisis, FDI based growth is usually not sustainable in the long term. On the basis of our calculations and graphs it has become obvious that CEECs - as periphery economies - are highly volatile to exogenous shocks. We may conclude that such dependent market economies are not likely to continue their convergence and their competitiveness is also a temporary characteristics during the growth periods. In the long run, such weaknesses as the lack of human or social capital will probably lead to even greater tensions. Although growth tendencies have been quite diverse among the analysed economies, countries like Hungary have not only become dependent on foreign capital but due to the increasing proportion of assembling activities, the presence and economic engagement of multinational companies have also turned into quite a risky factor within the country group (Gál \& Schmidt, 2016). The "triad" of the relatively cheap workforce, assembling activities as well as the increasing role of shared service centres may contribute to the further deepening of economic volatility and even hinder the future development of the given countries.

As a next conclusion, it has to be highlighted that Central Eastern European growth has also strongly relied on the high consumption of the group. Besides the lack of investments, an exceeded consumption has been maintained in the region despite the relatively low incomes of the population. Thus it is not surprising that savings within the domestic sectors are low. Since inner consumption is lower than production, external account deficit has led to a significant current account deficit.

In light of the above-mentioned results and reasoning it is still an open question whether true catching-up might be realized in Central Eastern Europe. As for Hungary, after having carried out some calculations it turns out that the long term economic growth rate of the country is $1.77 \%$ for the period of 1920 and 2016. On one hand, latter rate might refer to a transit between the state of divergence to convergence or on the other, to a so-called steady-state level where further permanent growth is practically impossible. In such cases middle-income traps may emerge and provoke some severe stagnation phases, as it has been shown in case of Hungary as well as Poland. According to the available data and some historical experience we may conclude that convergence might be achieved only by introducing certain conditions. Besides expanding the export activity it would be also a requirement to produce high value added products. Since the CEE region is wellequipped with skilled workforce, this advantage should be further enhanced by the constant training of the workers within several strategic sectors (Labaye et al., 2013). What is more, investments should be initiated towards technological modernisation. As a possible direction of development, countries of Central Eastern Europe should utilize one of their biggest competitive advantage, the agricultural production (Labaye et al., 2013). Although currently latter area requires serious investments as well as complete reorganisation, it might become a leading economic sector of the CEECs providing the Union with high quality plant and also animal products.

\section{Acknowledgements}

This research was supported by the ÚNKP-17-3 New National Excellence Program of the Ministry of Human Capacities. 


\section{References}

Attila, M. (2013). Európai gazdasági és politikai föderalizmus (european economic and political federalism). Dialóg Campus.

Beneš, V., \& Braun, M. (2014). An Ever-closer Eurozone and Its Consequences for Differentiated Integration in Europe. In S. Blockmans (Ed.), Differentiated Integration in the EU. From the Inside Looking Out. Centre for European Policy Studies (CEPS). http://aei.pitt.edu/47672/1/Differentiated_Integration_in_the_EU.pdf.

Bieńkowski, W. (2016). Post Communist Countries of Central Eastern Europe Facing Middle Income Trap Problem: Preliminary Findings Based on Statistical Data and Some Factor Analyses for 1990-2014. Myśl Ekonomiczna i Polityczna(2 (53)), 66-96.

Bureau of Economic Analysis. (2017). U.S. Economic Accounts. https://www. bea.gov/.

Cywiński, Ł., Harasym, R., Pater, R., \& Tarchalski, K. (2016). Intangible Capital, Level of Economic Growth, and "Middle Income Trap". Studia Ekonomiczne/Polska Akademia Nauk. Instytut Nauk Ekonomicznych(3 (90)), 439-461.

EBRD. (2017). Transition Report 2017-18 (European Bank of Reconstruction and Development). http://2017.tr-ebrd.com/downloads/.

EUROSTAT. (2017). Statistical Database. http://ec.europa.eu/eurostat/data/ database.

Fraser Institute. (2017). Economic Freedom. https://www.fraserinstitute.org/ economic-freedom/map?geozone=world\&page=map\&year=2015.

Garrett, G. (2004). Globalization's Missing Middle. Foreign Affairs.

Gál, Z., \& Schmidt, A. (2016). Geoeconomics in Central and Eastern Europe: Implications of FDI. In J. M. Munoz (Ed.), Advances in Geoeconomics. Routledge.

Golonka, M., György, L., Kruliš, K., Pokrywka, ., \& Vaňo, V. (2015). Middle-Income Trap in $V_{4}$ Countries? - Opening theses (The Kosciuszko Institute).

Groningen Growth and Development Center. (2013). The Maddison-Project. http:// www.ggdc.net/maddison/maddison-project/data.htm.

Hüttl, A., Surányi, B., \& Vita, L. (1998). A Gazdasági Növekedés és Fejlettség Paradoxona a Kelet-közép-európai Átmenetben [The Paradox of Economic Growth and Development Level in the East-Central-European Transition]. Közgazdasági Szemle (Economic Review-monthly of the Hungarian Academy of Sciences), 45(11), 973-988.

Janossy, F. (1969). Gazdaságunk mai ellentmondásainak eredete és felszámolásuk útja [Root Causes of Current Contradictions in Our Economy and Their Treatment]. Közgazdasági Szemle (Economic Bulletin), 16(7-8), 7-8.

Kornai, J. (2005). Közép-Kelet-Európa Nagy Átalakulása-siker és Csalódás [The Great Transformation of Central and Eastern Europe-success and Disappointment]. Közgazdasági Szemle (Economic Review-monthly of the Hungarian Academy of Sciences), 52(12), 907-936.

Központi Statisztikai Hivatal (KSH) (Central Statistical Office). (2007). A Gazdasági Fejlettség Alakulása a Kelet-közép-európai Régiókban [Development of Economic Development in the Central and Eastern European Regions]. Statisztikai Tükör (Statistical Support), 1(54), 1-5. https://www.ksh.hu/docs/hun/xftp/stattukor/ gazdfejlkke.pdf. 
Központi Statisztikai Hivatal (KSH) (Central Statistical Office). (2010). Magyarország 1989-2009: A Változások Tükrében [Hungary 1989-2009: In the Light of the Changes] (Tech. Rep.). https://www.ksh.hu/docs/hun/xftp/idoszaki/mo/mo1989 _2009.pdf.

Központi Statisztikai Hivatal (KSH) (Central Statistical Office). (2017). Magyarország 2016 [Hungary 2016] (Tech. Rep.). http://www.ksh.hu/docs/hun/xftp/idoszaki/ mo/mo2016.pdf.

Labaye, E., Sjåtil, P. S., Bogdan, W., Novak, J., Mischke, J., Fruk, M., \& Ionut, O. (2013). A New Dawn: Reigniting Growth in Central and Eastern Europe. https://www.mckinsey.com/ /media/McKinsey/Global\%20Themes/Europe/ $\mathrm{A} \% 20$ new $\% 20$ dawn $\% 20$ Reigniting $\% 20$ growth $\% 20$ in $\% 20$ Central $\% 20$ and $\% 20$ Eastern $\%$ 20Europe/MGI_CEE_A_new_dawn_Full_report_Dec_2013.ashx. McKinsey Global Institute.

Majone, G. (2012). Rethinking European Integration after the Debt Crisis (The European Institute, London's Global University Working Papers, No. 3).

Martin, A., \& Ventura, J. (2010). Economic Growth with Bubbles (National Bureau of Economic Research Working Papers No. 15870). doi:10.3386/w15870

Narodowy Bank Polski (Central Bank of Poland). (2017). Balance of Payments Statistics. http://www.nbp.pl/homen.aspx?f=/en/statystyka/Balance_of_payments.html.

National Bank of Hungary. (2017). Balance of Payments, Foreign Direct Investment, International Investment Position. https://www.mnb.hu/en/statistics/statistical -data-and-information/statistical-time-series/viii-balance-of-payments -foreign-direct-investment-international-investment-position.

Podkaminer, L. (2013). Development Patterns of Central and East European Countries (in the Course of Transition and Following EU Accession) (The Vienna Institute for International Economic Studies, Research Reports, No. 388). https:// wiiw.ac.at/development-patterns-of-central-and-east-european-countries -in-the-course-of-transition-and-following-eu-accession--dlp-2985.pdf.

Rapacki, R., \& Próchniak, M. (2009). The EU Enlargement and Economic Growth in the CEE New Member Countries) (European Economy Economic Papers No. 367). doi: $10.2765 / 23063$

World Bank. (2017). World Development Indicators. https://data.worldbank.org/ data-catalog/world-development-indicators. 